\title{
Converging and Diverting at the Time of Death Exploratory Routes for the Study of Death Among Muslims and Jews in Britain
}

\author{
Marta Dominguez Diaz* \\ Centre for the Study of Muslim-Jewish Relations
}

\begin{abstract}
Despite the existing wealth of literature on death studies, research on death rites among Muslim and Jews is still scarce. The present article is an exploration of literature on death studies that will help us to elaborate a conceptual frame which may allow the study of death in Jewish and Muslim communities to be better understood. It examines the uneasy relationship between religion and death studies by looking in particular at Islam and Judaism and it explores potential lines of research for further developing the academic field of Jewish and Muslim mortuary practices. It argues that central to our understanding of religious death cultures is an appreciation of the nuanced ways in which the universal and local dimensions of world religions like Judaism and Islam emerge. It presents some examples to illustrate how written and fieldwork sources can be used in the study of death in Judaism and Islam with the aim of considering the general as it is illuminated by the particularities of specific case-studies.
\end{abstract}

\section{Introduction}

Death, being the unavoidable matter that it is, has always drawn people's attention, especially that of artists, theologians and scholars. For social scientists, death has long been an object of curiosity and fascination, and it is a topic well established in anthropological literature. Studies dealing with death have not only examined the diverse practices relating to the disposal of the dead body, and the mortuary rites associated with them, they have also explored the meanings attached by different cultures to the processes that constitute the end of a person's life and examined how changes in society affect the ways in which individuals and communities understand and ritualise death. A seminal interest in the study of death left a valuable theoretical legacy in the works of Durkheim (1966 [1897]), Evans-Pritchard (1968 [1937]), Hertz (1960), Malinovsky (1954 [1925]), Mauss(1979), van Gennepp (1960 [1909]) and Radcliffe-Brown (1964 [1912]) among others. They were the first to conceptualise death beyond its biological dimensions, as a primarily social event, the impact and significance of which expanded beyond the actual moment in which a person's life ceases to be. A number of ethnographies have been inspired by the early scholars and approached death in this broader sense (e.g. Battaglia 1990; Brandes 2001; Cátedra 1992; Conklin 2001; Danforth 1982; Heilman 2001; Klima 2002; Robben 2000; Rosaldo 1980; Scheper-Hughes 1992).

Frequently the underlying rationale that sustains most of the existing literature on the topic is the acknowledgement of an enduring relationship between the living and the dead, of the fact that the biologically dead person retains a remarkable social presence in the community to which they belonged. This complex connection between the dead and the living is manifested in symbolic ways, in the various cultural contexts analysed, and is 
the reason why scholarship has for so long recognised how closely intertwined death is with the social identity of the living. Social scientists' interest in mortality does not lie in death per se but in the implications it has for the social and cultural mechanisms developed by those still living (e.g. Bauman 1992). The connection between death and social identity is so intimate that the study of the former is generally carried out with a view to exploring the latter. In the process of individual identification with the group, religion plays a significant role; religion, the 'sacred canopy' - provider of meanings to structure reality (Berger 1967) - has a direct effect on social identity and makes meaningful the nature of human interaction. Consequently, one might expect the study of religion to play a central role in death studies. Yet, aside from theological perspectives that discuss how religious thought perceives death (e.g. Davies 2008; Lamm 2000; O'Flaherty 1988) there have been relatively few studies that explore how religions, in their social dimensions, deal with life and death today. The present article is an exploration of literature on death studies that will help us to elaborate a conceptual frame which may allow the study of death in Jewish and Muslim communities to be better understood. It examines the uneasy relationship between religion and death studies by looking in particular at Islam and Judaism. ${ }^{1}$

\section{Death Studies and the Monotheistic Faiths}

If we take a closer look at the study of mortality within the three monotheistic faiths, some remarkable differences appear between them. Studies dealing with Christian understandings of death are the most abundant. They evince a diversity of approaches which is difficult to find in studies of practices in Islam and Judaism. Christian studies of mortuary practices include not only explorations that deal strictly with Christian theological 'universals' (e.g. Davies 2008) but also examinations of particular contexts (e.g. Brandes 2001; Danforth 1982; Scheper-Hughes 1992). Characteristic of these approaches is the stress placed on the contextualised nature of religious life, and the identification of the ways in which people perceive meta-narratives of a theological character in relation to their own cultural singularities. There have been some attempts to produce contextualised ethnographical literature on death pertaining to Muslims and Jews, but these are relatively few and are concise studies rather than comprehensive monographs. The most significant exception is Heilman's (2001) work, an eloquent anthropological personal account of Jewish rites of death and bereavement in the United States. The study is enriched by his personal immersion in the ways in which death is experienced and handled by the members of a chevra kaddisha, a religious society of devoted men who are in charge of the ritual cleaning and shrouding of the corpse in preparation for burial. The author also travels to Israel to see how Jewish mortuary practices among the orthodox community in America compare to the same practices in Jerusalem.

Nothing of comparable depth and scholarly insight exists for the study of death in Islam, an area in which could be found only a number of articles which were generally more limited in scope. Abu-Lughod's (1993) exploration of female responses to death among the Awlad 'Ali Bedouins of Egypt is a good analysis of the ways in which the 'great' and the 'little' traditions of Islam are continually juxtaposed in imbuing death with meanings for the living. She is particularly insightful in discussing the intrinsic difficulty of studying world religions in their manifold 'glocal' dimensions. Earlier authors (e.g. Redfield 1956) tried to solve the problem by advancing a model which proposed to categorise religion in terms of its 'great' and 'little' traditions. According to this approach, world religions have a twofold component: (a) the 'great tradition' which refers to the 
orthodox, textual tradition, the one which travels worldwide, and (b) the 'little tradition', characterised as heterodox, peripheral, eminently local and popular (quoted in LukensBull (1999, p. 4)). Despite the neatness of this theoretical paradigm, one might argue that its application to the study of religious life has always proved to be challenging. Thus, the commonest approaches that have been developed insofar are either theological perspectives concerned with religious 'universals' (i.e. meta-narratives) or anthropological studies dealing merely with the 'particulars' of a case-study, with their characteristic 'thick descriptions' of the phenomena analysed. Overall, most attempts have failed to grasp the holistic dimension, one which considers at the same time the universals and the particulars, the great and the little traditions. Abu-Lughod (1993) explores the interplay between the two in illuminating ways. But this type of approach is not common. Generally speaking, whereas philosophers, theologians and others have largely been concerned with the exploration the 'great traditions', social scientists have mainly been preoccupied with the 'little traditions'. As a result, analyses of the interaction between the two are somewhat scarce. The great/little tradition dichotomy which emerged out of an attempt to study the social organisation of religion 'as a whole' with its global and local components intermingling in complex ways, has largely been ignored. Abu-Lughod's (1993) seems to be a remarkable exception. Her study brilliantly illustrates how female funeral laments among the Awlad 'Ali are informed by ideas peculiar to their particular cultural setting along with others characteristic of Islamic moralities worldwide. More interestingly, she discusses how the local and the global appear sometimes to be at odds with one another with local practices sometimes constituting transgressions of an Islamic code of conduct. For example, Abu-Lughod argues that when women in grief tear their clothes and appear unveiled in front of men in public spaces, they are consciously performing an act of transgression that symbolises the devastating power and subversive nature of death itself (1993, pp. 202-3).

Though not abundant, there certainly are other studies of death among Muslim communities. None of them, however, seem to identify the mixed sourcing (i.e. cultural/religious, global/local and so forth) of the narratives invoked and rituals displayed at the time of death. For example, the valuable account of the symbolism of life and death in a Moroccan community by Pandolfo (1997) is extremely detailed yet it lacks any reference to the global meta-narratives that inform Muslim life everywhere. Her work is nonetheless an inspiring and original way of putting together source material of a very varied nature - speech, poetry, maps, drawings and so on. Other interesting ethnographic accounts that focus on local meanings and practices can be found in the works of El-Aswad (1987), Yamani (2004) and Bowen (1984). Similarly, Jewish studies have produced scholarly materials on ritual responses to death (e.g. Fishbane 1989; Goldberg 1982; Shay 2004). In the next section, I shall attempt to explore some lines of inquiry which may prove useful in developing the still-in-its-infancy field of death studies in Muslim and Jewish societies. Most of what I propose is based on my own experience of conducting research among Muslim and Jewish communities of diverse cultural backgrounds and various sectarian affiliations in Britain.

\section{Death Studies and Religion: The Risk of Essentialising}

If the study of death is to incorporate both universals and particulars I would argue that the enterprise of comparison remains central. Between the theologians' focus on metanarratives and the anthropologists' concern for cultural specificities, there has to be a methodology that enables death to be studied in its cross-cultural, cross-religious and 
trans-historical forms. Apart from the exceptions we have discussed (e.g. Abu-Lughod 1993; Heilman 2001) scholarly attempts at dealing with global and local forces that do not take a comparative approach run the risk of essentialising the religious tradition studied. Cornell's (2007) serves to illustrate this point. Hers is an exploration of 'death in Islam' that is based on the death of a Muslim in California. She uses this case to illustrate some of the Islamic beliefs that are common to most if not all Muslim contexts (e.g. the need for speedy burial, the stance against autopsies and so forth). However, some traits, particular those relating to the author's Moroccan background, are taken by her to be general characteristics of the Muslim world. For example, she argues that in 'the Muslim World' young women are not supposed to clean and prepare the body for burial (2007, p. 152). However, other research suggests that in some places Muslims believe that the washers have to be both the same sex as the deceased and also members of deceased's family - so washers may include young females (e.g. Yamani 2004). Cornell's work, despite presenting valuable insights into how transnationalism shapes death rituals among some Muslims in California, seems to assume a 'pristine' religious conception of ritual which is supposedly recognised by Muslims worldwide, but which does not in fact exist. I would suggest that by considering contextualised case studies one often becomes aware of how difficult it is to make generalisations in the study of death. Furthermore, the study of diaspora communities provides a valuable opportunity to compare various religious cultures and their diverse understandings of death and ritual. I would offer for consideration the thought that the global/local dyad could be more successfully addressed. For example, my own research indicates that there are some areas of Egypt where there is a widespread belief that decorating graves with flowers is an 'un-Islamic' practice, whereas among some Bangladeshi communities the relatives of the deceased dedicate a great deal of their time every week to cleaning the graves and ornamenting them with flowers. Burial sites of the Muslim diaspora, such as Woodgrange Park cemetery in London, ${ }^{2}$ are good examples of how diverse approaches to grave decoration symbolise different things for different ethnic groups, whilst testifying to the fact that what is seen as unlawful by some is widely endorsed by others. Burial sites of this kind provide inspiring opportunities to explore intrareligious diversity in relation to death.

\section{Consolidating 'Religious Communities'}

The study of death in Muslim and Jewish communities not only faces the challenge of dealing with the kaleidoscopic nature of religious identity within the two religions, but it also poses interesting questions about how religious discourses and practices are legitimised. Religious meanings are fluid, often indeterminate, and subject to transformation. However, most religious devotees would present their core religious beliefs about a particular matter, for example death, as a unified, consistent and unchanging body of thought. In most of the accounts they give, their own religions display clear sets of norms that invariably apply everywhere in a transcultural and ahistorical way. There are certain exceptions to this, mostly evidenced by members of religious subgroups or 'sects', whose religious choices are those of a 'minority' and are perceived as such by themselves as well as by members of the 'mainstream' religion. Regardless of whether they are in fact a numerical minority, it is the notion of 'schismatism' which is often linked to them which influences them to elaborate religious narratives in a rather different way. Illustrative of this would be the liberal Jews and Ismaili Muslims I came across during my research into mortuary rites. One interviewee, for example, who 
describes herself as a liberal Jew, elaborates on this sense of 'outsiderness' when talking about mourning: "Whereas in Judaism mourners sit shiva for three days, we [liberal Jews] just give our condolences one evening." 3 Interesting here is the sense of singularity endorsed; although such interviewees still consider themselves to be Jews, accounts like this seem to imply that in their view they are not part of 'normative' religion.

This contrasts with a more common perspective in which people present their own religiosities as representative of a more general trend, if not 'the whole'. For example a young Muslim respondent said: "We Muslims believe that the soul of the deceased comes to encounter the living when we visit his grave; Islam teaches us to visit people's graves in order to be good Muslims." It cannot be said that respondents like her are unaware of the diversity within their own religion, yet when I asked whether this belief in the soul visiting the grave is common to all Muslims, she asserted emphatically: "This is what Islam tells us and if a Muslim tells you otherwise he does not know enough about his religion." The fact that the belief in the soul visiting the grave does not seem to be particularly widespread among Muslims in Britain is not important here: what is telling is how mechanisms of identity construction become so apparent in rituals of death. Hence, we may infer that not acknowledging other religious orientations is to make a point about normativity, about how things are believed to be and 'supposed' to be, rather than about how they are. That is to say, the idea that there is one 'adequate' set of beliefs and associated death ritual practices indicates a particular view of power relations within religious communities. Although death rites are certainly not the only arena in which issues of religious legitimacy may be explored, they are particularly revealing of how the normative is diversely understood and expressed. At the same time they illustrate how speech contains subtle verbal strategies that enhance and legitimise notions of religious authority and what is considered religiously correct.

An especially interesting aspect of studying the death rights of diaspora 'communities' is the fact that migrant groups tend to reconfigure kin ties in the host land, creating 'new' communities. Life-cycle rituals are often at the centre of how and why these new communities emerge and death rituals have been shown to be particularly good at enhancing the sense of belonging to a broader, yet often 'imagined', community. The Jewish and Muslim communities in Britain, I would suggest, are of an 'imaginary' nature because they differ from actual communities in that their constitution does not depend on members knowing each other or interacting on a daily basis - instead they are based on the feeling of camaraderie that emerges among people who do not necessarily know each other. ${ }^{4}$ In the case of Muslims and Jews in Britain, the sense of 'religious affinity' (i.e. the assumption that all the members of the community share a set of beliefs) is what primarily creates the sense of belonging to the group. The shared assumption that all members of this 'community' perform ritual practices associated with death in the same way is a key building block in the construction and consolidation of religious identity; furthermore, it strengthens the sense of belonging to a large religious community of individuals or small groups, who would not necessarily have identified with one another prior to the experience of migration. Studying the transformations that have taken place in Muslim and Jewish mortuary practices in Britain over several generations tells us a great deal about the ways in which feelings of affinity among groups of migrants have been modified, and how these feelings have given rise to 'imagined religious communities'. Most obviously this is attested to by the frequency with which interviewees refer to 'the Muslim community' or 'the Jewish community', when presumably such references would hardly occur in pre-migration settings. 


\section{Between the Prescribed and the Performed}

Both Jewish and Muslim 'communities' produce a wealth of literature on the topic of death: some of the works deal with ritual aspects, others present 'religiously inspired' ways of coping with absence, whilst yet other groups of texts aim to orient social behaviour and help the bereaved to make sense of their loss. In this research I have explored the literature that Jews and Muslims in Britain read on the topic of death and it is surprising how similar the texts are. In the case of Islam, most of them are booklets produced by local mosques or Muslim organisations and they generally address practical issues related to the funeral. Many people, especially younger ones, download material from the internet. The most common language is English, whilst quite a few people read items in Arabic or Urdu. The code of ritual practice outlined in most of these booklets is remarkably similar; there seems to be a wide consensus on, for example, what Muslims should do at a funeral. These booklets reveal the development of the ritual homogenisation discussed in the previous section, and I would suggest that this may be seen as an attempt to consolidate religious legitimacy. At the same time it indicates the importance of studying oral as well as written sources to gather a comprehensive picture of death rites in a given context. If written sources were to be considered uncritically - without being contrasted with individual accounts and informal speech - one might easily assume, for example, that Muslims in Britain wrap the deceased's body in a white cloth before burying it. In fact, analyses of case studies reveal, for example, that among some groups with a Syrian background, bodies are covered in a green cloth. This custom is also preserved by some groups in the Arabian Peninsula who believe that green is the colour of paradise (Amrou 1985 , p. 354). Another case where what is prescribed in writing is at variance with what actually constitutes ritual practice can be seen in the decoration of graves. Whereas the vast majority of booklets recommend maintaining graves without decoration (because it is believed that austerity at the time of death is commanded by the teachings of Islam) Muslim peoples all around the world have meticulously decorated graves for centuries. We know, for example, of the graves of religious and political leaders, and we know of the intricate patterns displayed on the tombs of mullähs and vizīrs and Muslims 'saints' (awliy $\vec{a})$. But it is not only important people who deserve exquisitely decorated graves; one need only take a walk in any of the Muslim burial sites that exist in Britain today to see how communities of various cultural backgrounds (e.g. areas of Turkey and Pakistan) decorate tombs with plants and flowers because it is believed that this will make the journey into Barzakh (the place in which the soul of the deceased is believed to stay after the person's death and before Judgement Day) more pleasant. Nevertheless, the fact that religious praxis is not always congruent with the written sources does not mean that the written sources should not be considered at all. They provide us with valuable information about death rites and how these rites manifest particular intra-religious dynamics. An example of this can be found when we look at issues considered to be sensitive among British Muslims. For example, whereas there are booklets which explicitly state that women should stand in the back rows during worship, there are none which say that women are prohibited from attending funerals. And though the opinion that they shouldn't attend them is quite widespread, the fact that this is considered a highly sensitive issue means that such a prohibition would not normally be included in a booklet published in the United Kingdom today. ${ }^{5}$ It would be of interest to understand the reason for omissions such as this, and to discover to what extent censoring these voices is a new reality of the post-9/11 context. This also highlights the contrast between written materials and fieldwork data, and gives us a more realistic picture of ritual performance. 


\section{Between Collective Norms and Individual Choices}

The gap which may appear between the prescribed and the performed makes us aware of the need to address written sources in a critical way, and it also underlines the importance of fieldwork materials (e.g. informal speeches, semi-structured interviews and so on). The following example illustrates this. Sources often cite the fact that one of the Jewish (and Muslim) prescriptions with regard to death is to bury the body. However, some Jews prefer to be cremated. With regard to this, some interviewees see burying as the rule, and cremation as uncommon, which results 'not from tradition but from people's individual choice. It is atypical for a religious person to be cremated'. Yet if one looks at trends of body disposal among Jews in Britain, one becomes aware of the fact that cremation is not an isolated option, chosen by specific individuals, nor is it even the 'choice' only of Jews who consider themselves to be non-religious. The 2007 report of the Board of Deputies of British Jews estimates that $11 \%$ of the total number of deaths recorded among British Jews were cremations. ${ }^{6}$ The majority of those who chose to be cremated were liberal Jews, and a far smaller proportion of them were Reform Jews. However, actual numbers of cremations are probably much higher than these figures suggest because all those represented in the survey are linked to a Jewish synagogue through formal Jewish lifecycle rituals, such as circumcision, marriage, burial or cremation. It might well be that Jews who are not members of a synagogue tend to be less religiously observant - as indicated by the interviewee quote above - or at least to observe in a less 'traditional' way and be more likely to choose the form of disposal more common among gentiles. The number of Jews who 'choose' to be cremated is great enough for us to suggest that it is connected with broader societal trends, and also with the fact that some assimilationist tendencies have pervaded Jewish mortuary practices among certain groups. By contrast, most of the Jewish interviewees who refer to cremation, do so as if it were a choice made by individuals on the fringes of Judaism. Conducting comparative research opens up the possibility of identifying common patterns and of attributing some attitudes to societal tendencies and not to the mere personal choice which the respondents' accounts sometimes suggest.

Another area in which fieldwork material needs to be collated and analysed is to do with the shomer. Jewish tradition prescribes that the body of the deceased should not be left alone at any time between the moment of death and burial. The shomer (in Hebrew literally meaning 'guardian') is the person entrusted to care for the corpse, who sits near the deceased and recites psalms to 'accompany' the body. Whereas several of the people interviewed have commented on how the demands of modern life make it more difficult for a person to have the time to be a shomer, the attitudes displayed on these matters by various groups of Jews differ. Some of the followers of liberal and Reform Judaism would have a family member acting as the shomer. Sometimes there seems to be no requirement that the shomer should be the same sex as the deceased. In other cases, there is no shomer at all as the practice is considered 'a reminder from the past with no actual meaning today'. In some congregations members of the same synagogue take on the duty of being the shomer, as this is perceived as an act of camaraderie that strengthens intra-communal ties. Among most orthodox groups, the shomrim are professionals who are paid to accompany the body, and here a strict gender etiquette is followed (shomer and deceased being of the same sex). The professional shomer does not necessarily know the deceased or the relatives. Although many interviewees present the act of paying a professional shomer as a 'choice', the decision largely depends on how well accepted the practice is among members of the synagogue in question. Members of congregations that tend to disapprove of 
the practice will generally not consider it, whereas members of groups in which it is a fairly normal practice would not consider not having a professional shomer, believing it to be 'something every person should have when [he or she] dies'.

\section{Concluding Remarks}

The present article has discussed some of the exploratory routes that might be taken in the study of death among Jewish and Muslim populations. I have suggested that central to our understanding of religious death cultures is an appreciation of the nuanced ways in which the universal and local dimensions of world religions like Judaism and Islam emerge. Much of what I have said can be extrapolated to other world religions, as the social dimensions of religious life may sometimes manifest in correlative ways all around the world. It may also be that there are some universal aspects to death practices that arise from human nature, and which are not necessarily framed by particular cultural or religious forces. However, much of what I have discussed here points towards the importance of cultural specificity, even when death is framed with notions which belong to theological commands that are recognised by members of a given religion in various parts of the world. Contrary to the widespread assumption in the existing literature of a 'Jewish or a Muslim way of death', I have contended that much of what people do at the time of death is determined by contextual forces. The article suggests that there is a process of consolidation of the notion of a 'religious community', linked to the diaspora context. I have presented some examples to illustrate how written and fieldwork sources can be used in the study of death in Judaism and Islam with the aim of considering the general as it is illuminated by the particularities of specific case-studies. Events such as death are often the source of intra-religious competition, and mortuary rites often evidence the values and the forms of ritual and disposal that will predominate. Ultimately, this article illustrates the fact that the ways in which people deal with death can tell us a great deal about the social identity of the living.

\section{Acknowledgement}

I am grateful to the Centre for the Study of Muslim-Jewish Relations for funding a 2-year research project on the meanings attached to death by Muslims and Jews in Britain. This article is part of this project.

\section{Short Biography}

Marta Dominguez Diaz is an anthropologist of religion who specialises in the study of Islam and in Islam and Judaism in a comparative perspective. Her research interests include Islamic rituals, Muslim and Jewish death rituals, transnational Sufi Orders, NorthAfrican Sufism and European Islam. After finishing her undergraduate in History at the University of Barcelona, she moved to London, where she undertook a MA Islamic Societies and Cultures and a PhD Study of Religions at the School of Oriental and African Studies, University of London. Her $\mathrm{PhD}$ explored female religious identities in the transnational Order Qādiriyya by looking at the ways in which religious discourses are corporeally endorsed by female devotees of this Order. The study proposed a comparative perspective between diverse of its Moroccan and Western European enclaves. She is working on turning the thesis into a monograph and has published a number of articles on the topic. Marta is currently a research fellow at the Centre for the Study of 
Muslim-Jewish Relations-Woolf Institute in Cambridge, where she has embarked into a 2 -year research project. Following her interest on the Abrahamic faiths as living traditions, and in understanding how are they manifested by individuals and communities in ritual praxis, she has continued to investigate embodiments of religious meanings. In this new project she expands her interest in the anthropology of Islam by proposing an examination of religious variations in attitudes towards death, dying and grief among Muslims and Jews in Britain. She is interested in comparing the ways in which individuals and communities respond to death in these two traditions.

\section{Notes}

* Correspondence address: Marta Dominguez Diaz, Centre for the Study of Muslim-Jewish Relations, The Woolf Institute, Wesley House, Jesus Lane, Cambridge CB5 8BJ, UK. E-mail: md527@cam.ac.uk

${ }^{1}$ For an interesting insight into the comparative study of death between Judaism and Islam from a historical perspective, see Astren (2003).

${ }^{2}$ For an inspiring exploration of the ways in which the dead remain part of the lives of the living through processes of memorialisation see Francis et al. (2005).

3 Shiva, in Hebrew literally meaning seven, is the term used to refer to the period of mourning that the closest relatives (i.e. the deceased's parents, siblings, spouse and children) are expected to observe. During this time, regular activity shall be interrupted. The number seven refers to the amount of days that the mourning is expected to last. The seven day length is nowadays observed mainly by Orthodox Jews, whereas most of the Conservative and Reformed groups mourn for shorter periods, typically of 3 days.

4 This notion of an imagined community was first formulated by Benedict Anderson (1991) with reference to the creation of national sentiments.

5 Two Muslim interviewees have suggested that it would nowadays be difficult to find a publication advocating for female prohibition to attend funerals in the UK. It was argued that this is not related to religious but to the political context, with many Muslims feeling they are being treated with suspicion by the state. The respondents further suggested that views that can be seen as having a potential to be identified as 'extremist' have gradually been selfcensored by Muslim communities all over the country.

${ }^{6}$ Information available online at: http://www.boardofdeputies.org.uk/file/CommunityStatistics2007.pdf, accessed on the 29th November 2010.

\section{Works Cited}

Abu-Lughod, L. (1993). Islam and the Gendered Discourses of Death, International Journal of Middle East Studies, 25, pp. 187-205.

Amrou, M. A. A. (1985). Al-Libās wal-Zinā fil-Shari'a al-Islamiyyā. Amman: Dar al-Furqan.

Anderson, B. (1991). Imagined Communities. London \& New York: Verso.

Astren, F. (2003). Depaganizing Death: Aspects of Mourning in Rabbinic Judaism and Early Islam. In: J. C. Reeves (ed.), Bible and Qur'an: Essays in Scriptural Intertextuality, pp. 183-99. Atlanta: Society of Biblical Literature.

Battaglia, D. (1990). On the Bones of the Serpent: Person, Memory, and Mortality in Sabarl Island. Chicago: University of Chicago Press.

Bauman, Z. (1992). Mortality, Immortality and Other Life Strategies. Cambridge: Polity Press.

Berger, P. L. (1967). The Sacred Canopy: Elements of a Sociological Theory of Religion. New York: Doubleday.

Bowen, J. R. (1984). Death and the History of Islam in Highland Aceh, Indonesia, 3(38), pp. 21-38.

Brandes, S. (2001). The Cremated Catholic: The Ends of a Deceased Guatemalan, Body \& Society, 7(2), pp. 11120.

Cátedra, M. (1992). This World, Other Worlds: Sickness, Suicide, Death and Afterlife Among the Vaqueiros de Alzada of Spain. Chicago: University of Chicago Press.

Conklin, B. (2001). Consuming Grief: Compassionate Canibalism in an Amazonian Society. Austin: University of Texas Press.

Cornell, R. E. (2007). Death and Burial in Islam. In: V. Cornell and G. Henry-Blakemore (eds.), Voices of Islam, Voices of Life: Family, Home and Society, vol. 3, pp. 151-72. London: Praeger.

Danforth, L. M. (1982). The Death Rituals of Rural Greece. Princeton: Princeton University Press.

Davies, D. J. (2008). The Theology of Death. London \& New York: T \& T Clark.

Durkheim, E. (1966 [1897]). Suicide: A Study in Sociology. New York: The Free Press. 
El-Aswad, E. (1987). Death Rituals in Rural Egyptian Society: A Symbolic Study, Urban Anthropology and Studies of Cultural Systems and World Economic Development, 16, pp. 205-41.

Evans-Pritchard, E. E. (1968 [1937]). Witchcraft, Oracles and Magic Among the Azande. Oxford: Clarendon Press.

Fishbane, S. (1989). Jewish Mourning Rites, a Process of Resocialization, Anthropologica, 31, pp. 65-84.

Francis, D. et al. (2005). The Secret Cemetery. Oxford: Berg.

van Gennepp, A. (1960 [1909]). The Rites of Passage. Chicago: University of Chicago Press.

Goldberg, H. (1982). Funerals and Bereavement Rituals of Kota Indians and Orthodox Jews, Omega, 12(2), pp. 117-28.

Heilman, S. C. (2001). When a Jew Dies: The Ethnography of a Bereaved Son. Berkeley: University of California Press. Hertz, R. (1960). Death and the Right Hand. London: Cohen and West.

Klima, A. (2002). The Funeral Casino: Meditation, Massacre, and Exchange With the Dead in Thailand. Princeton: Princeton University Press.

Lamm, M. (2000). The Jewish Way in Death and Mourning. New York/Princeton: Jonathan David/Princeton University Press.

Lukens-Bull, R. (1999). Between Text and Practice: Considerations in the Anthropological Study of Islam, Marburg Journal of Religion, 4(2). Electronic version.

Malinovsky, B. (1954 [1925]). Magic, Science and Religion. New York: Doubleday \& Company.

Mauss, M. (1979). Sociology and Psychology: Essays. London: Routledge.

O'Flaherty, W. D. (1988). The Origins of Evil in Hindu Mythology. Delhi: Motilal Banarsidass.

Pandolfo, S. (1997). Impasse of the Angels: Scenes From a Moroccan Space of Memory. Chicago: University of Chicago Press.

Radcliffe-Brown, A. R. (1964 [1912]). The Andaman Islanders. New York: The Free Press.

Redfield, R. (1956). The Little Community. Viewpoints for the Study of a Human Whole. Chicago: Chicago University Press.

Robben, A. (2000). State Terror in the Netherworld: Disappearance and Reburial in Argentina. In: J. A. Sluka (ed.), Death Squad: The Anthropology of State Terror, pp. 151-70. Philadelphia: University of Pennsylvania Press.

Rosaldo, M. Z. (1980). Knowledge and Passion: Ilongot Notions of Self and Social Life. Cambridge: Cambridge University Press.

Scheper-Hughes, N. (1992). Death Without Weeping: The Violence of Everyday Life in Brazil. Berkeley: University of California Press.

Shay, T. (2004). Who Takes Care of the Loved Ones? Anthropological Quarterly, 77(2), pp. 289-301.

Yamani, M. (2004). Cradle of Islam: The Hijaz and the Quest for an Arabian Identity. London \& New York: I. B. Tauris. 